taking of one fact or principle from one science, and another froun some other and putting them together, I call a horlgrepodge. Can that be callecl science?" The answer 1 take almost verbatiö̀ from, Dean Parker's buok, mentioned above: "If a student who is presented with a problem concerning ventidation, for example, has to scarch for relevant material from various soures he may be toing the highest grande of logical, reflective thinking. "Tf he keeps his problem clearly in mind, if he searches for evilenee in an unbiased manner, if he rejects irrelevant material, if he arranges and urganizes his ideas, if he formulates and rerilies his conclusions, he is being logical in the highşst sense, he is being scientifically minded, he is acquiring skill in the use of scientific method, and he is on the riglit road to become a scientist. .

And right there, to ine, is one of the greatest values to be. gained from the study of general science. Dr. Bagley has made the point that halits are transferrel only when they become conscious ideals. And I firmly believe that this subject offers far. greater possibility in this regard for pupils of the junior high school age than does the science of physiography. It provides a. great possibility for a training in scientific method to the end that the pupil may appreciate the value of scientific knowledge in solving the problems of later life, and may-nse- the scientific method in their solution. This is an ideal which I strive to hold betore the pupils in my own classes."

\title{
Obstacles in the Path of General Science
}

Froxk M. Grewitiw, Rogers High School, Newport, R. I.

Teti subjects added to the high school curriculum in recent years have attained such widespread popularity as general science. The pressire for courses of study which eliminate latin aud algebral from the work of the first year of the high school and the increasing tendency to regard typewriting and stenography as licter placed in the later years of commercial courses have created a demand for work which ean profitnlyly be given in the first or scoud year. Plysical geography, commereial geography, biology have been tried but not generally accepted. Now comes general science; and administrators all over the country have hailed this as a convenient means of Alling a program, a receptacle into which all pupils might be gathered who were not fitted for the 
'higher 'things' of the traditional routine. İerein lies one of the chief dangers-to fie lasting. success of the new movement.

Further, there is serious objection ta the introduction of un:differentiated work it a school which is professedly higher thair an-elementary schoel. Thiere is nafurally wide difference of opinion on this joint; but the strong tendency towards early differentiation of courses which has led to the establishment of junioj: high schools carries with it differentiation of subject matter ig. scnior high schools. Where suen separation of grades is acconplished, it appeais that-general science belongs to the lover râthẹ. than to the higher.yroup of grades.'

$A$ third diffieulity arises from the large number of pupils for whom provision has to be made and the lack of a broad eqnipment on the part of nuany teachers who are called ipon to teacls general science. It has been wirll said that this work demands the-best teaching that the scicnce department has to give. Perhaps no other subject is so well adapted, in piroper liands, to aronse the self-activity of the jutpid, to cultrinte his initiative and resourcefulness. Few, if any, suljocts leriti themselrés so reádily aña helpfully to social applications. "The girt or loy of today who-cannot run an automohile -is almgst ar cxception- Pupils often know much more about wireless than, their science teachers: Herg are basic attainment and interest wijeb areduphicates in many fields. Even the '-movics' provide a starting point if attention is stifted to the projection apparatus or the cinkung camera. And that teacher is wise who sets the Therses of nofejir seionce-over against the lurid. heroes of the screen. What I wish to snggest is that the work in general scienco; to be worth while, inust start from and follow the science experience anclinterest of the pupil, that so far as possible the pupil should determine the direction of the work and. share in responsibility for:the success or:filive of the result.

There will be some administrators who prefer the comfortable order of things in which the teacher assigns ench day three or four pages of the text for tomorrow's recitation. I tet us be charitable. Perlaps we to once followed the casicst wiyl. 